\title{
Motivations and Benefits of Student Volunteering: Comparing Regular, Occasional, and Non-Volunteers in Five Countries
}

\author{
Karen A. Smith \\ Victoria University of Wellington, New Zealand \\ Kirsten Holmes \\ Curtin University, Australia \\ Debbie Haski-Leventhal \\ University of New South Wales, Australia \\ Ram A. Cnaan \\ University of Pennsylvania, USA \\ Femida Handy \\ University of Pennsylvania, USA \\ Jeffrey L. Brudney \\ Cleveland State University, USA
}

\begin{abstract}
Programs targeting student volunteering and service learning are aimed at encouraging civic behaviour among young people. This article reports on a large-scale international survey comparing volunteering among university students in Australia, Canada, New Zealand, the United Kingdom, and the United States. The data revealed high rates of student volunteering and the popularity of occasional volunteering. It also revealed that other young people were the main beneficiaries of students' voluntary activities. Student volunteers were influenced by a mix of motivations and benefits, with differences on a continuum of volunteer involvement between those volunteering regularly, those volunteering occasionally, and those not volunteering.
\end{abstract}

\section{RÉSUMÉ}

Les programmes d'initiation au bénévolat et au service à la collectivité destinés aux étudiants ont pour but d'encourager le développement du comportement citoyen chez les jeunes. Cet article fait état d'une étude internationale à grande échelle effectuée auprès d'étudiants de niveau post-secondaire universitaire - en Australie, au Canada, en Nouvelle-Zélande, au Royaume-Uni et aux États-Unis. Les 
données ont révélé qu'un taux élevé d'étudiants font du bénévolat, que le bénévolat occasionnel est populaire et que les principaux bénéficiaires du bénévolat étudiant sont aussi des jeunes. Les étudiants sont influencés par une combinaison de motivations et de bénéfices, et les différences entre les étudiants qui font du bénévolat régulièrement, ceux qui en font à l'occasion et ceux qui n'en font pas s'inscrivent dans un continuum d'engagement bénévole.

Keywords / Mots clés Volunteering; Voluntary action; University students; Cross-cultural research; Motivations / Bénévolat; Action bénévole; Étudiants universitaires; Recherches interculturelles; Motivations

\section{INTRODUCTION}

In recent years Western governments have sought to encourage civic behaviour among young people, and volunteering has emerged as one avenue for this process. There has thus been an increase in volunteer programs for school and university students. One example is the growth in community service and service learning programs. Student volunteering is regarded by governments as essential to perpetuate an engaged civil society (Haski-Leventhal et al., 2008). However, students face a number of barriers to volunteering, such as the rising costs of education and the need to undertake more paid work, thus reducing the time available to volunteer (Evans \& Saxton, 2005). Some young people also have a negative perception of volunteering as "not cool," "boring," and time-consuming, based on stereotypical views of volunteering (Commission on the Future of Volunteering, 2008; Davis Smith, 1999; Niyazi, 1996).

Governments and the nonprofit sector have sought to address these negative attitudes and increase participation in volunteering. Youth in particular are targeted, for evidence suggests that young people are likely to be socialized into pro-social (e.g., volunteering) behaviour (Hooghe \& Stolle, 2003). This observation is supported by data showing that people who volunteer while in school are more likely to volunteer later in their lives (Astin \& Sax, 1998; Janoski, Musick, \& Wilson, 1998). Youth volunteering initiatives are frequently based around educational institutions, including the tertiary level such as universities. Examples include Campus Compact in the USA and investment through the Higher Education Active Community Fund in the U.K. These education-based programs are usually called "service learning" or "community service" and can be optional or mandatory. Although service learning programs are a growing trend globally, research on their impact on participants and on future volunteer participation has been inconclusive (Berry \& Chisholm, 1999), particularly the impacts of mandatoryalso known as compulsory—programs (Taylor \& Pancer, 2007).

Student volunteering can be broadly defined, and the National Co-ordinating Centre for Public Engagement (NCCPE, n.d.) points to the inclusion and exclusion of various activities within the definitions of U.K. universities. Student volunteering is sometimes conceptualized as outward-looking, focusing on students volunteering within their local communities, although this activity may be organized through their university. The external focus can result in some educational institutions excluding (some) internal volunteering roles, where students volunteer within the university, student union/association, and studentled clubs and societies. The positioning of curriculum-based volunteering and service learning with an element of compulsion attached is also variable. This diversity of definitions has implications for how we understand, measure, and develop student volunteering. In this research we utilize a broad definition of student volunteering that includes a range of activities both internal and external to the university setting.

ANSERJ To be notified about new ANSERJ articles. click subscribe. 
Our aim in this article is to examine the extent to which university students participate in volunteering and how students perceive the motivations and benefits associated with volunteering. These are common topics for volunteering research; however, we seek to understand how motivations and benefits are associated with the frequency of volunteering by comparing those students volunteering regularly, those volunteering occasionally, and those not volunteering. We report on a cross-national study of university student volunteering in five Western, predominantly English-speaking countries: Australia, Canada, New Zealand, the United Kingdom, and the United States. Data were collected through a self-administered survey. The literature review on student volunteering, motivations, and benefits leads to two sets of hypotheses, both of which are proposed and tested empirically here. These hypotheses concern the relationships between student volunteering participation and frequency in the five countries; and the relationship between frequency of student volunteering (regular, occasional, and non-volunteer) and the motivations and benefits associated with volunteering.

\section{LITERATURE REVIEW}

We begin our review of the literature by considering the similarities between the five countries studied here: Australia, Canada, New Zealand, the United Kingdom, and the United States. Studies examining the extent and characteristics of student volunteering in each country are discussed, and we reflect on the lack of comparable cross-cultural data. We then examine the dominant motivations and benefits of student volunteering.

Most of the studies on student volunteering have been undertaken in the United States (Haski-Leventhal et al., 2008), although there is a growing focus on this area in the United Kingdom (e.g., Holdsworth, 2010; NCCPE, n.d.) and some Australian research on volunteering within individual academic programs (e.g., Auld, 2004; Esmond, 2000; McCabe, White, \& Obst, 2007). The Johns Hopkins Comparative Nonprofit Sector Project established strong similarities across the third sectors in Australia, New Zealand, the United Kingdom, and the USA. These countries form the "Anglo-Saxon" cluster based on their large nonprofit sector but have lower levels of government support compared to higher levels of fee income and private philanthropy (Salamon, Sokolowski, \& List, 2003; Sanders, O'Brien, Tennant, Sokolowski, \& Salamon, 2008). Although Canada is outside this group and sits with many mainland European countries in the "Welfare Partnership" cluster; it shares the characteristics of a large nonprofit sector. Both clusters have a sizeable volunteer presence compared with other countries in the Johns Hopkins Comparative Nonprofit Sector Project. The five countries studied here share similar conceptualizations of formal volunteering as carried out in an organizational context, usually, but not always, in a nonprofit organization.

It has been argued that there is variation between these five countries regarding the role of service learning within university education; for example, with service learning being more integrated in the United States and Canada than in the United Kingdom (Holdsworth \& Quinn, 2010). Overall, there may be greater homogeneity across English-speaking countries. For example, in Canada, 7\% of 20- to 24year-olds reported that they were participating in mandatory community service (Hall, Lasby, Ayer, \& Gibbons, 2009), mirroring the $6.9 \%$ of students in England who reported that they were required to volunteer as part of their study program (Holdsworth, 2010). Many Australian and New Zealand universities have student volunteering programs, and some are moving toward a compulsory service learning element.

ANSERJ To be notified about new ANSERJ articles. click subscribe. 


\section{Smith, Holmes, Haski-Levenhal, Cnaan, Handy, \& Brudney (2010)}

Holdsworth and Quinn (2010) point to a lack of reliable data on the rates and characteristics of student volunteering, and this contributes to the challenge of finding data that allow international comparisons. In the absence of dedicated data on student volunteering, we must look to studies of volunteer participation more generally. Reliable national-level statistics exist on volunteering participation in each of the five countries discussed in this article. However, methodological differences and an absence of cross-cultural studies make comparing this data difficult. Even the World Values Survey is of limited use here, for Australia and New Zealand did not take part in the fourth wave of the survey (1999-2004) that asked questions on unpaid work. National studies of volunteering do report rates for youth volunteering (although the age of the youth cohort used does vary between countries). For example, in the 2007 Canada Survey of Giving, Volunteering and Participating, young people (aged 15-24) had the highest participation in volunteering (58\% compared to $46 \%$ of all respondents) (Hall et al., 2009). One must be cautious when equating youth volunteering with student volunteering. Although the majority of university students fall within the youth age cohort, not all young people are university students, and not all university students are young people.

There is a widely accepted positive association between the level of educational attainment and volunteering (see Finlay \& Murray, 2005). This suggests that volunteering rates will be higher among students than among the general population within these age categories. This conjecture is supported by data from the Australian Voluntary Work Survey (Australian Bureau of Statistics, 2007), which found that the volunteering rate for students aged 18 to 24 years was $43.4 \%$, compared to $20.1 \%$ for those of the same age who were not classified as students. There was scant difference between the volunteering rates for full-time and part-time students ( $42.6 \%$ and $44.9 \%$, respectively). These data support the notion that university students have a higher rate of volunteering than the average for their age cohort.

Also supporting this notion, a large longitudinal study found $15.3 \%$ of English students had volunteered with a charity during their first year at university (Holdsworth, 2010). A study of British student experiences cited by Holdsworth and Quinn (2010) indicated that $15 \%$ of students from four universities were involved in voluntary work: $7 \%$ in volunteering organized through their university and $11 \%$ in volunteering organized in other ways, with some students doing both. These two U.K. studies were of general student populations, and three Australian studies on student participation in volunteering within specific tertiary classes/programs found even higher levels of involvement. In two different Australian universities, McCabe et al.'s study (2007) of psychology students found a $43 \%$ volunteering rate, the same as Esmond's earlier study (2000) of social work and psychology students (44\%). Across leisure studies, human movement studies, and movement science (kinesiology) programs in three Queensland universities, Auld (2004) found that $36.1 \%$ of students were currently volunteering.

Regardless of the level of current volunteering, a key message in many initiatives to increase youth and student volunteering is the development of more flexible volunteering opportunities (NCCPE, n.d.; and see the Russell Commission on youth action and engagement, 2005). This movement toward flexibility reflects other evidence that the nature of volunteering has changed-an unintended consequence of modernity (Dekker \& Halman, 2003; Hustinx \& Lammertyn, 2003; Wuthnow, 1998). Individuals are switching from regular and long-term to shorter-term, episodic, or occasional volunteering, a change that is especially popular among young people. People seek out and engage in short-term experiences that will fulfill their immediate and timely needs, and they sometimes move on to other fulfilling experiences (Handy, Brodeur, \& Cnaan, 2006). Macduff (2005) classified episodic volunteering along a time continuum: temporary (volunteering only for a short time); interim (volunteering on a regular basis but for 
a defined period, for example on a project); and occasional (volunteering for short periods of service at regular intervals).

Volunteering is, therefore, an increasingly heterogeneous activity that occurs along a continuum, with long-term regular volunteers at one end and occasional volunteers at the other end (Hustinx, HaskiLeventhal, \& Handy, 2008). This variability in participation requires further consideration in relation to student volunteers, who have generally been considered as a homogenous group in terms of participating (a volunteer) or not (a non-volunteer). We group our student respondents on the basis of frequency of participation, and our research questions how different levels of volunteer participation (regular, occasional, non-volunteer) are associated with the perceived motivations and benefits of student volunteering.

\section{Motivations and benefits of student volunteering}

Young people volunteer for different motives and benefits than older people. A major motivator for young people is the opportunity to gain work-related experience, skills, and qualifications that can help them in their education and careers (Eley, 2003). For example, "to learn new skills" was the second most important reason for volunteering among the 16- to 24-year-old age group in the U.K. ${ }^{1}$ (Low, Butt, Ellis Paine, \& Davis Smith, 2007), and more than half of 15- to 19-year-olds in Canada said they had volunteered to improve their job opportunities (Hall, Lasby, Gumulka, \& Tryon, 2006). Volunteering brings outcomes, or impacts, for students, communities, education institutions, and employers (Holdsworth \& Quinn, 2010; NCCPE, n.d.).

There are multiple benefits from volunteering (Hall et al., 2009; Musick \& Wilson, 2008). Astin and Sax's (1998) U.S. research found that volunteering can enhance students' academic development, personal skills development, and sense of civic responsibility. Benefits were also associated with career choice and employability after graduation. The U.K.'s Russell Commission (2005) highlighted the importance of an employability agenda for young people (NCCPE, n.d.). Instrumental motives and benefits-such as those relating to career development-dominate the volunteering discourse as students recognize the need to build their personal capital (Holdsworth \& Quinn, 2010). However, these career-related factors exist alongside a variety of other motivations and benefits. A national study of university students in England found that respondents gave both altruistic and instrumental reasons for volunteering (Holdsworth, 2010). The most important reasons for volunteering were as follows: to help someone in their community; to learn new skills; to respond to their needs or skills; and, to help gain experience to benefit their future career.

Much of the research on motivations and benefits of volunteers has focused on collecting data only from active volunteers. Holdsworth and Quinn (2010) point out the lack of a control group of non-volunteers in most research studying the impact of volunteering on students. An Australian study by McCabe et al. (2007) compared perceptions of the reasons for volunteering between volunteer and non-volunteer students. Using the Volunteer Functions Inventory (VFI) developed by Clary, Snyder, and Stukas (1996), both volunteer and non-volunteer students rated values (e.g., reinforcement or expression of personal values) and understanding (e.g., personal growth) as the most important volunteer functions. Indeed, the only significant difference, in this case, between the cohorts was that non-volunteers rated the career function (for example, work skills and contacts) more highly than volunteers. 


\section{HYPOTHESIS}

We have previously noted (Haski-Leventhal et al., 2008) that a cross-cultural perspective on student volunteering is missing, despite research showing differences between volunteering in different countries. This article presents data on student volunteering at universities in five countries that share some commonalities in terms of their political, social, and cultural histories and their volunteering sectors: Australia, Canada, New Zealand, the United Kingdom, and the USA. We expect to find a preference among these university students for occasional rather than regular volunteering, thus our first hypothesis is as follows:

H1 More students who volunteer will be involved in occasional volunteering than regular volunteering

The article also aims to investigate the relationship between frequency of student volunteering and the motivations and benefits of volunteering. While acknowledging the multiplicity of motivations, the literature review emphasizes the importance of instrumental and career motivations for student volunteers. McCabe et al.'s research (2007) suggests differences between volunteer and non-volunteer students pertaining to career motivations. This research leads to four related hypotheses:

H2a Students will perceive a variety of motivations and benefits of volunteering, with instrumental motivations being most important

$H 2 b$ Regular student volunteers will perceive altruistic motivations and benefits as more important than occasional student volunteers and non-volunteer students

H2c Occasional student volunteers will perceive social motivations and benefits as more important than regular student volunteers and non-volunteer students

H2d Non-volunteer students will perceive instrumental motivations and benefits as more important than regular and occasional student volunteers

\section{METHODS}

To test our research hypotheses, we use data from a survey of over 4,000 university students who were surveyed in five countries using a common survey instrument. The data are extracted from a larger study examining student voluntary action across 14 countries (see Handy et al., 2010; Haski-Leventhal et al., 2008). In each country a member of the research team distributed questionnaires to a minimum of 600 university students. Data were collected in the 2006-07 academic year for Canada, the U.K. and the USA and in the 2008 academic year in Australia and New Zealand. In each country the sample was one of convenience and often was limited to one or a few universities. In each of Australia, New Zealand, and the U.K., data were collected at a single publicly funded university; in Canada data were collected at three universities and in the United States at six universities.

As Burns, Toncar, Reid, Anderson, and Wells (2005) have demonstrated, different universities (at least in the United States) produce different levels and types of volunteering. To decrease possible bias, in each country, over 600 university students in each country completed the questionnaire. Questionnaires were 
administered to students during their classes across a range of disciplines and faculties (social sciences, humanities, business and economics, natural sciences, engineering). Where classroom access was not permitted, some surveys were administered electronically. All students in each class were invited to participate on an anonymous basis, and survey completion was voluntary. Although refusal rates were not officially recorded, we note that they were relatively small (in the neighbourhood of $0.05 \%$ in classrooms, but higher when approached outside the classrooms). The survey received university ethics or human subject board approval from each university involved in the study. Although all of the participants were English-speaking, the questionnaire was slightly adapted to the local situation, culture, and system of public education.

The survey focused on formal volunteering, defining volunteer experiences as "giving freely of your time to help others through organizations." A broad definition of student volunteering was utilized, covering activities that were both internal and external to the university setting. Students were asked if they had volunteered in the last 12 months in eight types of organizations: religious organizations, human service organizations, sport or cultural organizations, community organizations, student clubs or other university organizations, neighbourhood organizations, local activist groups, and youth organizations. Students were also asked how often they volunteer. Here we classify those selecting "weekly" or "monthly" as regular volunteers and those selecting "occasionally" as occasional volunteers. The "occasional" volunteers engaged in time-delimited activities or events less than once a month. In this categorization we follow Handy et al. (2006), who use terms such as "genuine" versus "habitual" to distinguish between these types of volunteers. The survey also included students who were not volunteers.

To determine their motivations for volunteering as well as the motivations they attribute to other people, students were asked why they volunteer, and non-volunteers were also asked why they think (other) people volunteer, by agreeing or disagreeing with 15 statements (using a five-point Likert scale). The items were based on the Volunteer Function Inventory as developed by Clary et al. (1996) and were modified to include a number of instrumental motivations related to resumé building and work experience. These motivations are collected into three groups (see Handy et al., 2010). First, instrumental/careerrelated motivations related to resume building:

- to put volunteering on CV (resumé) when applying for a job;

- to put volunteering on CV for admission to higher education;

- to make new contacts that might help a business career; and

- to help one get a foot in the door for paid employment.

Second, altruistic/value-driven motivations:

- it is important to help others, to work for a cause that is important;

- to learn about a cause;

- to make one feel better; and

- to give one a new perspective.

Third, social/ego-defensive motivations were measured by the following items:

- to make new friends;

- because my friends volunteer;

ANSERJ To be notified about new ANSERJ articles. click subscribe. 
- people close to me influenced me to volunteer;

- I was advised to do so by a career advisor or family member;

- volunteering offers a good escape from one's troubles; and

- it relieves some of the guilt over being more fortunate than others.

Students also stated their level of agreement with 11 benefits of volunteering for the volunteer as derived from the literature (Hall et al., 2006; Musick \& Wilson, 2008). Altruistic/value-driven benefits were measured by:

- self satisfaction;

- the opportunity to learn new things; and

- development of trust among people in society.

Instrumental/career-related benefits were measured by:

- job/career experience;

- professional networking;

- references for employment or college;

- leadership skills; and

- fulfilling requisites for government or school program (service requirements).

Finally, social/ego-defensive benefits were measured by two items:

- social contact; and

- recognition from colleagues/friends.

Data were analysed using SPSS to compare across countries and between volunteers and nonvolunteers. For both motivations and benefits, we used cross-tabulations to examine differences between the responses of regular volunteers, occasional volunteers, and non-volunteers and the chi-square test to determine the statistical significance of any relationships.

\section{Profile of respondents}

The total number of questionnaires collected was 4,081. Respondents from North America constitute most of the sample, with about one-third (31.7\%) from the USA ( $n=1294)$ and one-quarter $(23.9 \%)$ from Canada ( $n=974)$. Australia ( $n=609)$, New Zealand $(n=605)$, and the U.K. $(n=600)$ each accounted for $15 \%$ of respondents. Approximately $60 \%(61.4 \%)$ of the respondents were female. The median age for all countries was 21 years. The majority of respondents $(68.2 \%)$ reported that they came from middleincome families. Domestic students, those completing their high school and university education in the same country, dominated the sample ( $85.1 \%$ overall), although in Australia more than a quarter of respondents had previously studied overseas.

\section{Results}

\section{Student participation in volunteering}


As shown in Table 1, across the entire sample of five countries, the student volunteering rate was over $70 \%(73.0 \%)$. This rate is higher than previous studies reported in the literature review, even those (such as Auld, 2004; Esmond, 2000; McCabe et al., 2007) that focused on volunteering on individual academic programs (36\% to $44 \%$ ), and much higher than the $15 \%$ reported in two U.K. studies of general student populations (Holdsworth, 2010; Holdsworth \& Quinn, 2010). Statistically significant differences in the rates of volunteering were found across countries. The highest rates were in Canada $(79.6 \%)$, the United States (78.8\%), and New Zealand (74.0\%). The United Kingdom (63.3\%) and Australia (58.7\%) had lower rates, but still higher than reported by the aforementioned studies (Auld, 2004; Esmond, 2000; Holdsworth, 2010; Holdsworth \& Quinn, 2010; McCabe et al., 2007).

\section{Table 1: Volunteering behaviour among student volunteers}

\begin{tabular}{|c|c|c|c|c|c|c|c|c|}
\hline & & 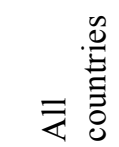 & 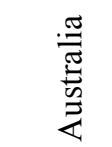 & 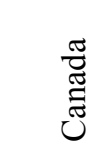 & z & $\underline{\ddot{y}}$ & $\begin{array}{l}\mathbb{N} \\
\text { D }\end{array}$ & $\mathrm{n}$ \\
\hline $\begin{array}{l}\text { Volunteering } \\
\text { rate** }\end{array}$ & $\begin{array}{l}\text { Volunteered in past } 12 \\
\text { months } \\
n=\end{array}$ & $\begin{array}{l}73.0 \% \\
4081\end{array}$ & $\begin{array}{l}58.7 \% \\
608\end{array}$ & $\begin{array}{l}79.6 \% \\
974\end{array}$ & $\begin{array}{l}74.0 \% \\
605\end{array}$ & $\begin{array}{l}63.3 \% \\
600\end{array}$ & $\begin{array}{l}78.8 \% \\
1294\end{array}$ & \\
\hline $\begin{array}{l}\text { Frequency of } \\
\text { volunteering } \\
* *\end{array}$ & $\begin{array}{l}\text { Regular } \\
\text { Occasional } \\
\mathrm{n}=\end{array}$ & $\begin{array}{l}35.6 \% \\
64.4 \% \\
2923\end{array}$ & $\begin{array}{l}31.1 \% \\
68.9 \% \\
354\end{array}$ & $\begin{array}{l}41.3 \% \\
58.7 \% \\
738\end{array}$ & $\begin{array}{l}33.2 \% \\
66.8 \% \\
461\end{array}$ & $\begin{array}{l}22.3 \% \\
77.7 \% \\
373\end{array}$ & $\begin{array}{l}39.0 \% \\
61.0 \% \\
997\end{array}$ & \\
\hline $\begin{array}{l}\text { Area of } \\
\text { volunteering }\end{array}$ & $\begin{array}{l}\text { Youth (mentor, tutor, } \\
\text { coach, } \\
\text { counsellor)** } \\
\text { Sport or cultural } \\
\text { activities* } \\
\text { University clubs or } \\
\text { organizations** } \\
\text { Health and emergency } \\
\text { services** } \\
\text { Community activities } \\
\text { (e.g., conservation, } \\
\text { animal welfare)** } \\
\text { Religious } \\
\text { organizations** } \\
\text { Neighbourhood or } \\
\text { activist groups** }\end{array}$ & $\begin{array}{l}48.2 \% \\
42.7 \% \\
39.4 \% \\
37.5 \% \\
32.6 \% \\
32.0 \% \\
14.3 \%\end{array}$ & $\begin{array}{l}45.5 \% \\
46.7 \% \\
27.8 \% \\
33.1 \%\end{array}$ & $\begin{array}{l}57.9 \% \\
44.7 \% \\
41.1 \% \\
38.3 \%\end{array}$ & $\begin{array}{l}37.1 \% \\
37.1 \% \\
25.8 \% \\
21.7 \%\end{array}$ & $\begin{array}{l}33.8 \% \\
40.2 \% \\
39.4 \% \\
25.5 \%\end{array}$ & $\begin{array}{l}52.6 \% \\
43.2 \% \\
48.5 \% \\
50.4 \% \\
39.5 \% \\
37.6 \% \\
19.5 \%\end{array}$ & $\begin{array}{l}1409 \\
1246 \\
1151 \\
1097 \\
953 \\
935 \\
419\end{array}$ \\
\hline
\end{tabular}

† Percentage of those volunteering in each country. ${ }^{* *}$ Significant at the 0.01 level. ${ }^{*}$ Significant at the 0.05 level

Students volunteer in a diversity of areas, and other young people are major beneficiaries of students' volunteering activities (Table 1). Almost half (48.2\%) of all student volunteers were involved as a mentor, tutor, coach, counsellor, or some other activity that benefited youth, and $39.4 \%$ volunteered for university clubs or organizations. The other main beneficiaries were sports and cultural organizations $(42.7 \%)$ and health and emergency services (37.5\%). The proportion of volunteers involved in each activity varied across countries $(p<0.01$, except sport $p<0.05)$.

Turning to hypothesis $\mathrm{H} 1$, Table 1 also presents data on the frequency of volunteering involvement. Of those volunteering, almost two-thirds of student volunteers (64.4\%) were occasional volunteers. There 
were higher levels of occasional compared to regular volunteering in all five countries. There are also significant differences between countries, with occasional volunteering being most evident in the U.K. (77\% of student volunteers). In Canada (58.7\% of student volunteers) and the USA (61.0\%) there were lower levels of occasional volunteering and conversely comparatively higher engagement in regular volunteering by students. Hypothesis $\mathrm{H} 1$-that more students who volunteer will be involved in occasional volunteering than regular volunteering-is supported.

\section{Motivations and benefits of student volunteering}

Hypothesis H2a-d concerns the motivations and benefits of volunteering and compares regular student volunteers (who are involved weekly or monthly), occasional student volunteers, and non-volunteer students. The percentages of regular, occasional, and non-volunteer respondents agreeing or strongly agreeing with each motivation item and each benefit of student volunteering are shown in Tables 2 and 3.

\section{Table 2: Motivations to volunteer ${ }^{\dagger}$}

\begin{tabular}{|c|c|c|c|c|}
\hline & Motivational item & $\begin{array}{l}\text { Regular } \\
\text { volunteers }\end{array}$ & $\begin{array}{l}\text { Occasional } \\
\text { volunteers }\end{array}$ & $\begin{array}{l}\text { Non- } \\
\text { volunteers }\end{array}$ \\
\hline \multirow[t]{4}{*}{$\begin{array}{l}\text { Instrumental/ } \\
\text { Career-related }\end{array}$} & $\begin{array}{l}\text { To put on CV (resumé) when applying for a } \\
\text { job ** }\end{array}$ & $61.5 \%$ & $65.1 \%$ & $70.6 \%$ \\
\hline & $\begin{array}{l}\text { To put on CV (resumé) for admission to } \\
\text { higher education ** }\end{array}$ & $58.0 \%$ & $61.5 \%$ & $67.0 \%$ \\
\hline & $\begin{array}{l}\text { To make new contacts that might help a } \\
\text { business career ** }\end{array}$ & $57.7 \%$ & $56.5 \%$ & $62.0 \%$ \\
\hline & $\begin{array}{l}\text { To help one get a foot in the door for paid } \\
\text { employment N.S. }\end{array}$ & $58.2 \%$ & $57.6 \%$ & $60.7 \%$ \\
\hline \multirow{5}{*}{$\begin{array}{l}\text { Altruistic/ } \\
\text { Value-driven }\end{array}$} & It is important to help others $* *$ & $90.2 \%$ & $85.7 \%$ & $79.2 \%$ \\
\hline & To work for a cause that is important $* *$ & $87.8 \%$ & $84.0 \%$ & $78.3 \%$ \\
\hline & Makes one feel better* & $75.4 \%$ & $71.6 \%$ & $68.0 \%$ \\
\hline & Volunteering gives one a new perspective $* *$ & $79.0 \%$ & $72.9 \%$ & $64.3 \%$ \\
\hline & To learn about the cause $* *$ & $63.7 \%$ & $57.1 \%$ & $55.9 \%$ \\
\hline \multirow{6}{*}{$\begin{array}{l}\text { Social/Ego- } \\
\text { defensive }\end{array}$} & To make new friends N.S. & $53.4 \%$ & $50.2 \%$ & $51.1 \%$ \\
\hline & $\begin{array}{l}\text { People close to me influenced me to volunteer } \\
*\end{array}$ & $42.0 \%$ & $43.3 \%$ & $41.5 \%$ \\
\hline & Because my friends volunteer $* *$ & $40.7 \%$ & $41.8 \%$ & $40.7 \%$ \\
\hline & $\begin{array}{l}\text { It relieves some of the guilt over being more } \\
\text { fortunate than others } * *\end{array}$ & $28.5 \%$ & $33.9 \%$ & $36.0 \%$ \\
\hline & $\begin{array}{l}\text { Was advised to do so by a career advisor or } \\
\text { family member ** }\end{array}$ & $29.1 \%$ & $30.5 \%$ & $35.5 \%$ \\
\hline & It's a good escape from one's troubles N.S. & $32.0 \%$ & $31.5 \%$ & $31.1 \%$ \\
\hline
\end{tabular}

† Volunteers: Why do you volunteer? Non-Volunteers: Why do you think people volunteer? Percentage of respondents strongly agreeing or agreeing.

** Significant at the 0.01 level. * Significant at the 0.05 level N.S. Not significant 
Table 3: Benefits of volunteering ${ }^{\dagger}$

\begin{tabular}{|llccc|}
\hline & & $\begin{array}{c}\text { Regular } \\
\text { volunteers }\end{array}$ & $\begin{array}{c}\text { Occasional } \\
\text { volunteers }\end{array}$ & $\begin{array}{c}\text { Non- } \\
\text { volunteers }\end{array}$ \\
\hline Instrumental/ & Job/career experience N.S. & $79.2 \%$ & $77.3 \%$ & $75.9 \%$ \\
& Provides references for employment or & $72.1 \%$ & $70.5 \%$ & $73.2 \%$ \\
& college N.S. & $83.8 \%$ & $72.7 \%$ & $65.3 \%$ \\
& Leadership skills ** & $64.2 \%$ & $59.8 \%$ & $60.7 \%$ \\
& Professional networking N.S. & $47.4 \%$ & $53.2 \%$ & $55.8 \%$ \\
\hline Service requirement ** & $83.2 \%$ & $80.1 \%$ & $77.4 \%$ \\
Valtruistic/ & Self-satisfaction * & $85.9 \%$ & $78.1 \%$ & $70.5 \%$ \\
& Opportunity to learn new things ** & $71.2 \%$ & $65.9 \%$ & $56.5 \%$ \\
\hline Social/Ego- & Builds trust among people in society ** & $75.1 \%$ & $70.6 \%$ & $70.1 \%$ \\
defensive & Social contacts N.S. & $43.0 \%$ & $41.6 \%$ & $46.5 \%$ \\
\hline
\end{tabular}

$\dagger$ In addition to helping others, what do you think the benefits of volunteering are for the volunteer? Percentage of respondents strongly agreeing or agreeing.

${ }^{* *}$ Significant at the 0.01 level. * Significant at the 0.05 level N.S. Not significant

The statistically significant results support a continuum based on the extent of involvement in volunteering (regular-occasional-non-volunteer) in relation to volunteers' stated motivations and the motivations perceived by non-volunteers (Table 2). "Important to help others"-an altruistic motivation-was the most important motivation for all three groups, but this motivation was significantly more important for regular volunteers $(90.2 \%$ agreed) than for non-volunteers $(79.2 \%)$, with occasional volunteers falling between the two $(85.7 \%)$. This regular-occasional-non-volunteer relationship-where the regular volunteers had the highest level of agreement-is also evident for three other altruistic items: "to work for a cause that is important," "volunteering makes one feel better," and "volunteering gives one a new perspective." The counter relationship is also evident. Non-volunteers had the highest level of agreement, followed by occasional and then regular volunteers, for two instrumental motivations: to put volunteering on the CV when applying for a job, or when applying for admission to higher education. This non-volunteeringoccasional-regular volunteering pattern continues for "relieves some of the guilt over being more fortunate than others," although this item had much lower levels of agreement (see Table 2).

These results support a continuum of volunteering motives by frequency of volunteering; however, three other results of the survey show occasional student volunteers may also be motivationally aligned with either non-volunteers or regular volunteers. Occasional and regular student volunteers had similar levels of agreement (56.5\% and $57.7 \%$, respectively) regarding the instrumental motivation "to make new contacts that might help a business career." These percentages were lower than for non-volunteers $(62.0 \%)$. About $30 \%$ of both occasional $(30.5 \%)$ and regular (29.1\%) volunteers reported that they "were advised to volunteer by a career advisor or family member," compared to $35.5 \%$ for non-volunteers. However, the motivation "to learn about the cause" had similar levels of agreement for non-volunteers $(55.9 \%)$ and occasional volunteers (57.1\%), both of which were lower than for regular volunteers $(63.7 \%)$. Occasional volunteers seemed to be slightly more influenced by peer pressure than regular volunteers or non-volunteers, $(43.3 \%$ agreed that "people close to me influenced me to volunteer" versus $41.5 \%$ of 
non-volunteers and $42.0 \%$ of regular volunteers). Other motivational statements had similar levels of agreement that were not statistically significant.

These patterns were also evident in respondents' answers to questions on the main benefits of volunteering for the volunteer. Ten benefits were presented (see Table 3); responses were again measured on a five-point Likert scale, and cross-tabulations used to compare the responses of regular, occasional, and non-volunteers. The regular-occasional-non-volunteer continuum is again evident in these results, where regular volunteers agreed most strongly, followed by occasional volunteers, then non-volunteers. This relationship occurs for three altruistic benefits: "opportunity to learn new things," "self-satisfaction," and "builds trust among people in society," as well as the more instrumental benefit of "leadership skills." The counter relationship occurs for the benefit "fulfilling requisites for government or school program," where non-volunteers (55.8\%) are similar to occasional volunteers $(53.2 \%)$, with fewer regular volunteers agreeing (47.4\%). Other findings on instrumental benefits and social contacts showed agreement that these were benefits of volunteering, but the results were not statistically significant across the three different levels of involvement in volunteering.

\section{DISCUSSION AND CONCLUSION}

This study aimed to examine patterns and attitudes toward volunteering among university students in different countries. We examined volunteering in five Western, predominantly English-speaking countries: Australia, Canada, New Zealand, the U.K., and the USA. with particular attention to the relationship between frequency of volunteering and perceived motivations and benefits. Students were divided into three subgroups: regular volunteers, occasional volunteers, and non-volunteers.

We found a high level of volunteerism among students across the sampled universities in these five countries. This finding could be seen as positive for educational institutions and governments that seek to encourage volunteerism by students and young people (Haski-Leventhal, Meijs, \& Hustinx, 2009). However, the high rates of volunteerism may be due in part to the survey method, for the study utilized a convenience sample. Students with some interest or experience in volunteering may have been more likely to complete the questionnaire, despite our efforts to survey all students, including non-volunteers. The high rates of participation may reflect the sampling method and not be representative of national student volunteer rates in the participating countries. And, as with much of survey research where participating in the survey is a voluntary activity, it is likely there is a further selection bias in that those who have a proclivity to volunteer may be indeed those who volunteer to participate in filling out surveys. Most of the universities in this study also have active campus-based volunteer programs, which may influence volunteer participation. Nevertheless, the inclusion of students across a range of faculties in each participating university suggests that previous discipline- or program-based studies (e.g., Auld, 2004; Esmond, 2000; McCabe et al., 2007) may have under-represented the extent of tertiary education student volunteering.

The study used a broad and inclusive definition of volunteering and the most popular beneficiaries of volunteer activities were youth-based, university clubs and organizations, and sports and cultural organizations. Many of these organizations are campus-based and therefore easily accessible to students. Educational institutions can use the attractiveness of these programs to draw students into volunteering, and should communicate the outcomes that students contribute to on campus to the wider student body. However, while students are active on campus, the wider nonprofit sector may not benefit to the same degree, with the exception of sport and cultural organizations. The university-basis for

ANSERJ To be notified about new ANSERJ articles. click subscribe. 
volunteering may have implications for these students' long-term involvement in volunteering postgraduation. Campus-based volunteering can be a route into volunteering, but encouraging activities offcampus suggests the need to build partnerships with local nonprofit organizations and volunteer resource centres to further develop existing university-community relationships. With higher levels of formaleducation achievement being a predictor of volunteering (Finlay \& Murray, 2005), university graduates should show strong propensity to volunteer. The legacy of university involvement and the transition of student volunteers into post-education volunteering both merit further research.

Other publications from this research project have extended this cross-cultural perspective and investigated country differences and the relationships between participation in volunteering, and variously students' vocational choices, involvement in service learning programs, and career-orientated motivations (Handy et al., 2010; Haski-Leventhal et al., 2008, 2010).

Occasional volunteering is popular among students and is also a factor in the high levels of volunteering reported. Although a continuum of volunteer involvement is by no means novel to the literature (see, for example, Hustinx et al., 2008), our inclusion of non-volunteers cements the importance of occasional volunteering as an activity between not volunteering and volunteering regularly. Occasional volunteering is a popular trend among university students, due to time limits and a tendency toward more reflexive and less collective type of volunteering activities among Generation $\mathrm{Y}$, also known as the echo-boom generation ${ }^{2}$ (Hustinx \& Lammertyn, 2003). These trends should be recognized and utilized to enhance students' "volunteerability" and their ability to volunteer (see Haski-Leventhal et al., 2009).

We further hypothesized that students perceive a variety of motivations and benefits of volunteering, with instrumental motivations being most important. This hypothesis $\mathrm{H} 2 \mathrm{a}$ was partly supported: students do recognize a mix of motivations and benefits from volunteering, but instrumental and career motivations are not statistically different from altruistic/value-driven motives and social/ego-defensive factors.

The findings show a significant correlation between frequency of volunteering and perceived motivations and benefits. Hypothesis $\mathrm{H} 2 \mathrm{~b}$, that regular student volunteers will perceive altruistic motivations and benefits as more important than occasional student volunteers and non-volunteer students, was supported. Regular student volunteers did report higher levels of altruistic motivations and benefits than the other two groups. There can be at least two explanations for these findings: first, that altruistic people tend to volunteer more than others; or second, that people who do volunteer may prefer to attribute to themselves positive traits such as altruism. In addition, Dekker and Halman (2003) argued that volunteers have a different ethos than non-volunteers.

Our hypothesis $\mathrm{H} 2 \mathrm{c}$, which proposes that occasional student volunteers will perceive social motivations and benefits as more important than other students, was only partially supported. Occasional student volunteers did report significantly more peer pressure motivations, but not to very high levels, and they did not associate with social benefits.

Hypothesis $\mathrm{H} 2 \mathrm{~d}$, which suggests that non-volunteer students will perceive instrumental motivations and benefits as more important than regular and occasional student volunteers, is also partly confirmed. Nonvolunteer students agree more strongly with some of the instrumental motivations, and regular student volunteers give more importance to the altruistic motivations and benefits. Occasional student volunteers are in between regular and non-volunteers, reflecting a continuum of volunteer involvement. Student volunteers value altruistic benefits more highly than non-volunteer students, but the results are 


\section{Smith, Holmes, Haski-Levenhal, Cnaan, Handy, \& Brudney (2010)}

inconclusive for instrumental and social contact benefits, with the exception of fulfilling service requirements. This finding confirms McCabe et al.'s (2007) study in which the only significant difference between student volunteers and non-volunteers was that the latter rated the career function more highly.

As in all research, this study has limitations that need to be considered. A cross-cultural study is always challenging, since the research instrument has to be slightly adapted. Cultural perceptions of the meaning of volunteering may limit the possibility of comparison. Furthermore, although the sample is heterogeneous, it is not random, and therefore rates of volunteering in general, and student volunteering regularly or occasionally, may be somewhat biased. We suggest additional research in more countries, particularly in post-communist countries and those in the developing world, to further investigate motivations and benefits of student volunteers in a multinational context.

Notwithstanding these aforementioned caveats, these findings demonstrate that students volunteer in various activities for different reasons. A practical implication would be to tap into the different types of volunteering and offer students short-term as well as long-term volunteering opportunities. Based on this study, we suggest that educational institutions and student groups encourage occasional volunteering by offering one-off group volunteering options and utilize social networks such as Facebook and university clubs to enhance occasional volunteering. Regular volunteers should be recognized for their ongoing contribution to the community. Finally, to recruit new volunteers among people who do not currently volunteer, educational institutions should endeavour to tie volunteering into career opportunities and highlight its instrumental benefits.

The findings of this study could be utilized to better target potential young volunteers by various nonprofits and promote community outreach by those volunteering with university clubs and societies. Nonprofits who wish to tap into students' preference for volunteering could tailor their programs, opportunities, and promotion materials accordingly. Links between on- and off-campus clubs would also be an important feature; for example, volunteering promoted as part of charity fundraising activities in orientation week (also known as frosh or freshers week). Finally, governments of the participating countries could promote volunteering among university students as an investment in the future of civil society and the provision of voluntary services. The growth of service learning programs (particularly those that are mandatory or compulsory) demonstrates a potential link between undertaking community service learning and achieving educational outcomes.

This research strengthens the arguments that tertiary education students engage in voluntary activities but, like other young people, prefer occasional participation in volunteering. Students who volunteer are active both within their university and in the wider community, and future researchers, educators, and policymakers would do well to recognize, and measure, both internal and external volunteering contributions. An important contribution of this research is to extend the continuum of volunteering beyond regular-occasional (or episodic) to include non-volunteers. Frequency of volunteering participation-including not volunteering-to some degree influences the motivations and benefits of volunteering, and further research inclusive of both active and non-volunteers will be valuable. This should include investigating the nuances of how students engage in occasional volunteering, for example, project and temporary involvements. Finally, cross-cultural research, although challenging, does enable theory development beyond a single or dominant worldview. 


\section{Smith, Holmes, Haski-Levenhal, Cnaan, Handy, \& Brudney (2010)}

\section{ACKNOWLEDGEMENTS}

The authors wish to thank the editor and anonymous reviewers for their guidance in focusing the paper and pointing out the complexities of occasional volunteering.

\section{NOTES}

1. The most important reason for volunteering for young people-and all other age groups—was "I wanted to improve things, help people."

2. There are no precise dates for Generation Y, but most commentators use birth dates between the mid to late 1970 s and the late 1990s; for example, Statistics Canada counts those born between 1980 and 1995. This population cohort is also referred to the echo-boom generation as they are often the children of baby boomers.

\section{REFERENCES}

Astin, A. W., \& Sax, L. J. (1998). How undergraduates are affected by service participation. Journal of College Student Development, 39, 251-263.

Auld, C. (2004). Behavioural characteristics of student volunteers. Australian Journal on Volunteering, 9(2), 8-18.

Australian Bureau of Statistics. (2007). Voluntary work, Australia. Canberra: Australian Bureau of Statistics.

Berry, H. A., \& Chisholm, L. A. (1999). Service learning in higher education around the world: An initial look. New York, NY: International Partnership for Service-Learning.

Burns, D. J., Toncar, M., Reid, J. S., Anderson, C., \& Wells, C. (2005). Volunteering: A comparison of the motivations of collegiate students attending different types of institutions. Journal of Volunteer Administration, 23(4), 31-40.

Clary, E. G., Snyder, M., \& Stukas, A. A. (1996). Volunteers' motivations: Findings from a national survey. Nonprofit and Voluntary Sector Quarterly, 25, 485-505.

Commission on the Future of Volunteering. (2008). Report of the Commission on the Future of Volunteering: Manifesto for change. London: Volunteering England.

Davis Smith, J. (1999). Poor marketing or the decline of altruism: Young people and volunteering in the United Kingdom. International Journal of Nonprofit and Voluntary Sector Marketing, 4(4), 372-377.

Dekker, P., \& Halman, L. (2003). Volunteering and values: An introduction. In P. Dekker \& L. Halman (Eds.), The values of volunteering: Cross-cultural perspectives (pp. 1-6). New York, NY: Kluwer.

Eley, D. (2003). Perceptions of and reflections on volunteering: The impact of community service on citizenships in students. Voluntary Action, 5(3), 27-46.

Esmond, J. (2000). The untapped potential of Australian university students. Australian Journal on Volunteering, 5, 3-9.

Evans, E., \& Saxton, J. (2005). The 21st century volunteer. London: NpfSynergy.

Finlay, J., \& Murray, M. (2005). Possible futures: Changes, volunteering and the not-for-profit sector in Australia. Melbourne: The Smith Family.

Hall, M., Lasby, D., Ayer, S., \& Gibbons, W. (2009). Caring Canadians, involved Canadians: Highlights from the 2007 Canada Survey of Giving, Volunteering and Participating. Ottawa, ON: Statistics Canada.

Hall, M., Lasby, D., Gumulka, G., \& Tryon, C. (2006). Caring Canadians, involved Canadians: Highlights from the 2004 Canada Survey of Giving, Volunteering and Participating. Ottawa, ON: Statistics Canada. 


\section{Smith, Holmes, Haski-Levenhal, Cnaan, Handy, \& Brudney (2010)}

Handy, F., Brodeur, N., \& Cnaan, R. A. (2006). Summer on the Island: Episodic volunteering in Victoria, British Columbia. Voluntary Action, 7(2), 31-46.

Handy, F., Hustinx, L., Kang, C., Cnaan, R. A., Brudney, J., Haski-Leventhal, et al. (2010). A cross-cultural examination of student volunteering: Is it all about resume building? Nonprofit and Voluntary Sector Quarterly, 39(3), 498-523.

Haski-Leventhal, D., Cnaan, R., Handy, F., Brudney, J. L., Holmes, K., Hustinx, L., et al. (2008). Students' vocational choices and voluntary action: A 12 nation study. Voluntas, 19(1), 1-21.

Haski-Leventhal, D., Grönlund, H., Holmes, K., Meijs, L. C. P. M., Cnaan, R. A., Handy, F., et al. (2010) Service-learning: Findings from a 14-nation study. Journal of Nonprofit \& Public Sector Marketing, 22(3), 161-179.

Haski-Leventhal, D., Meijs, L., \& Hustinx, L. (2009). The third party model: Enhancing volunteering through governments, corporations and educational institutes. Journal of Social Policy, 39(1), 139-158.

Holdsworth, C. (2010). Student volunteers: A national profile. London: Volunteering England/Institute of Volunteering Research.

Holdsworth, C., \& Quinn, J. (2010). Student volunteering in English higher education. Studies in Higher Education, 35(1), 113127.

Hooghe, M., \& Stolle, D. (2003) Age matters: Lifestyle and cohort differences in the socialisation effect of voluntary participation. European Political Science, 3(2), 9-56.

Hustinx, L., Haski-Leventhal, D., \& Handy, F. (2008). One of a kind? Comparing episodic and regular volunteers at the Philadelphia Ronald McDonald House. International Journal of Volunteer Administration, 15(3), 50-66.

Hustinx, L., \& Lammertyn, F. (2003), Collective and reflexive styles of volunteering: A sociological modernization perspective. Voluntas, 14(2), 167-187.

Janoski, T., Musick, M., \& Wilson, J. (1998). Being volunteered? The impact of social participation and pro-social attitudes on volunteering. Sociological Forum, 13(3), 495-518.

Low, N., Butt, S., Ellis Paine, A., \& Davis Smith, J. (2007). Helping out: A national survey of volunteering and charitable giving. London: Cabinet Office.

Macduff, N. (2005). Societal changes and the rise of the episodic volunteer. In J. L. Brudney (Ed.), Emerging areas of volunteering: ARNOVA Occasional Paper Series, 1(2), 49-61.

McCabe, T., White, K., \& Obst, P. (2007). The importance of volunteer functions to university students. Australian Journal on Volunteering, 12(2), 50-58.

Musick, M. A., \& Wilson, J. (2008). Volunteers: A social profile. Bloomington, IN: Indiana University Press.

NCCPE. (n.d.). Research synthesis: Student volunteering-background, policy and context. London:

National Co-ordinating Centre for Public Engagement.

Niyazi, F. (1996). A route to opportunity: Volunteering by young people. London: National Centre for Volunteering.

Russell, I. (2005). Report of the Russell Commission: A national framework for youth action and engagement. London: Her Majesty's Stationery Office.

Salamon, L. M., Sokolowski, S. W., \& List, R. (2003). Global civil society: An overview. Baltimore, MD: Center for Civil Society Studies, Johns Hopkins University.

Sanders, J., O'Brien, M., Tennant, M., Sokolowski, S. W., \& Salamon, L. M. (2008). The New Zealand non-profit sector in comparative perspective. Wellington: Office for the Community and Voluntary Sector. 
Taylor, T. P., \& Pancer, S. (2007). Community service experiences and commitment to volunteering. Journal of Applied Social Psychology, 37(2), 320-345.

Wuthnow, R. (1998). Loose connections: Joining together in America's fragmented communities. Cambridge, MA: Harvard University Press.

\section{About the authors}

Karen A. Smith, PhD, the corresponding author, is a Senior Lecturer at Victoria Management School, Victoria University of Wellington, PO Box 600, Wellington 6011, New Zealand. Email: karen.smith@vuw.ac.nz

Kirsten Holmes is a Research Fellow in the School of Management, Curtin University, Perth, Australia. Email: K.Holmes@,cbs.curtin.edu.au

Debbie Haski-Leventhal is NAB Research Fellow in the Centre for Social Impact at the Australian School of Business, University of New South Wales, Australia. Email: debbiehl@unsw.edu.au

Ram A. Cnaan is the Associate Dean for Research, Professor, and Chair of the Doctoral Program in Social Welfare, and Director of the Program for Religion and Social Policy Research at the University of Pennsylvania, USA. Email: cnaan@sp2.upenn.edu

Femida Handy is Professor in the School of Social Policy \& Practice, University of Pennsylvania, USA. Email: fhandy@sp2.upenn.edu

Jeffrey L. Brudney is the Albert A. Levin Chair of Urban Studies and Public Service at Maxine Goodman Levin College of Urban Affairs, Cleveland State University, USA. Email: j.brudney@csuohio.edu 